\title{
Moisture sorption characteristics of chhana murki
}

\author{
AS Khojare
}

Received: 02 August 2020 / Accepted: 30 October 2020 / Published online: 27 December 2020

(c) Indian Dairy Association (India) 2020

\begin{abstract}
Moisture sorption characteristics of Chhana murki were investigated at a temperature of $20^{\circ} \mathrm{C}, 30^{\circ} \mathrm{C}$, and $40^{\circ} \mathrm{C}$ using the static gravimetric method. Sorption curves obtained were sigmoid in shape and classified as type II. Equilibrium moisture content increased with an increase in water activity and decreases with an increase in temperature. Among the BET, GAB, and Caurie models tested, the BET and GAB models were found better to predict EMC data. BET monolayer decreased from 5.77 $\mathrm{g} \mathrm{H}_{2} \mathrm{O} / 100 \mathrm{~g}$ of solids at $20^{\circ} \mathrm{C}$ to $4.83 \mathrm{~g} \mathrm{H}_{2} \mathrm{O} / 100 \mathrm{~g}$ of solids at $40^{\circ} \mathrm{C}$. The $\mathrm{GAB}$ monolayer value decreased from $5.90 \mathrm{~g} \mathrm{H}_{2} \mathrm{O} / 100$ $\mathrm{g}$ of solids at $20^{\circ} \mathrm{C}$ to $5.14 \mathrm{~g} \mathrm{H}_{2} \mathrm{O} / 100 \mathrm{~g}$ of solids at $40^{\circ} \mathrm{C}$. The properties of sorbed water viz., number of adsorbed monolayer, percent bound and non-freezable water and surface area of sorption were determined using Caurie equation. Net isosteric heat of sorption decreased with a corresponding increase in moisture content, initially rapidly up to $15.89 \mathrm{~g}$ of water $/ 100 \mathrm{~g}$ of solids and then approaching a constant value.
\end{abstract}

Keywords: Chhana Murki, EMC, Sorption isotherm, Water activity

\section{Introduction}

Chhana Murki is a popular Indian milk product prominent in northern and eastern regions of the county. It is small size cubes coated with sugar possessed firm body and knit-like texture. It is

\section{Khojare AS $(\square)$}

Department of Dairy Science and Technology, Vivekanand College,

Samarth Nagar, Aurangabad, 431 001, M.S., India

Email:khojare@vivekanandcollege.edu.in prepared by heat desiccation of paneer cubes with sugar syrup in an open pan (Aneja et al.2002). Despite its great potential as ready to eat Indian convenience food, tit-bit food for children and having good shelf life due to sugar coating, the scope for organized marketing is limited. This is due to the lack of systematic studies on production, packaging and shelf life. For process upgradation, ready to eat food formulations, drying, packaging, and shelf-life determination, moisture sorption studies are very useful. Therefore, moisture sorption studies were carried out at the temperatures of $20^{\circ} \mathrm{C}, 30^{\circ} \mathrm{C}$ and $40^{\circ} \mathrm{C}$ to determine moisture sorption characteristics in Chhana murki.

Several mathematical models have been reported for assessing moisture sorption isotherms of foods by Boquet et al. 1978; Chirife and Iglesias,1978a; Van den Berg and Bruin,1981. Different properties of sorbed water could be obtained from the model proposed by Caurie (1981). The knowledge of temperature dependence of sorption phenomenon provides information for modeling and thermodynamics of the food system. The isosteric heat of sorption $\left(q_{\mathrm{st}}\right)$ yields a measure of water-solid binding strength via intermolecular attraction forces between the sorption sites and sorbet. The change in $q_{s t}$ with the change in the moisture content of the sample indicates the availability of polar sites to water vapor as the desorption/adsorption proceeds (Chung and Pfost, 1967).

Sorption isotherms of several western dairy products including milk powder, whey protein, lactose, casein, whey powder, yoghurt, and cheese have been reported, but the published report on Indian dairy products is limited. Information on moisture sorption isotherm of Kalakand (Deshmukh et al. 2018), Shrikhand (Khojare, 2018), Bottle Guard Burfi (Quadri et al. 2016), ChamCham (Puri and Khamuri, 2015), Sandesh (Khojare, 2014; Khojare and Hembade, 2015; Sahu and Das, 2010), Dietetic Rabri (Ghayal et al. 2013), Dietetic Chhana Kheer (Gautam et al. 2018), Peda (Biradar et al. 1985; Kumar et al. 2012), ready to use Basundi mix (Sharma et al. 2009), Curd powder (Varghese et al. 2008), Chhana podo (Rao et al. 2006.), Milk Burfi (Ramakrishna et al. 2005), Kheer (Jayendra Kumar et al. 2005), Dudh churpi (Hossain et al. 2002), Khoa (Sawhney and Cheryan, 1988) and Chhana powder and Casein (Bandyopadhyay et al. 1987) have been reported. However, the data on moisture sorption characteristics of Chhana 
murki was not available. Therefore, the research work was undertaken to determine the moisture sorption characteristics of Chhana murki at temperatures of $20^{\circ} \mathrm{C}, 30^{\circ} \mathrm{C}$ and $40^{\circ} \mathrm{C}$; to fit EMC models to data; to estimate properties of sorbed water and to obtain sorption thermodynamics parameters.

\section{Materials and Methods}

\section{Preparation of Chhana Murki}

Good quality cow milk obtained from the local market and standardized to $3.5 \%$ fat and $8.5 \%$ SNF was used for preparation of Chhana murki. Initially, milk was heated to $90^{\circ} \mathrm{C}$ and cooled to $70^{\circ} \mathrm{C}$. The hot milk was coagulated by using $1 \%$ solution of food-grade citric acid as an acidulant that was previously heated to the milk temperature, adding and stirring gently without breaking the coagulum, till the clear whey appears. The precipitation of milk involves the formation of large structural aggregates of protein. The whey formed during the process was removed by draining through the cleaned and sanitized muslin cloth by hanging the mass till the dripping of the whey ceased. The Chhana obtained is kneaded and formed into a $10 \mathrm{~mm}$ thick flat slab; it is then cut into small cubes of about $10 \mathrm{~mm}$. The cubes are cooked in boiling sugar syrup for five minutes with gentle stirring. The stirring is continued off heating till the sugar gets crystallized and coated uniformly around the cubes. After cooling Chhana murki is ready and may sprinkle with color and flavor and decorated with dry nut flakes (Aneja et al.2002). The proximate analysis of Chhana murki was carried out according to ISI,1981, and AOAC,2005 standards and obtained as moisture $28.58 \%$, protein $8.33 \%$, fat $9.45 \%$, ash $0.60 \%$, total sugars $53.04 \%$.

\section{Equilibrium moisture content (EMC) studies}

EMC data was obtained by using the static gravimetric method according to set up by Sablani et. al., (2001). The set up was made up of sample containers in a support beaker placed on glass beads support inside the wide mouth glass bottle with vapor tight lid. Each glass bottle contained different saturated salt solutions at the bottom up to the level of $0.4 \mathrm{~cm}$, represented specific relative humidity. The temperature was controlled by placing duplicate sorption containers in the thermo-regulated chamber maintained at $20^{\circ} \mathrm{C}, 30^{\circ} \mathrm{C}$, and $40^{\circ} \mathrm{C}$.

Ten reagent grade salt solutions in the water activity range of 0.11-0.97 adopted from Greenspan (1977) were used to equilibrate the product sample with the respective water activity. The salts were dissolved in distilled water to form saturated slush according to Jayendra Kumar et. al. (2005). The sorption containers were allowed to equilibrate to test temperatures for four days before 2 $\mathrm{g}$ of Chhana murki sample was placed into them. To prevent microbial growth $5 \mathrm{mg}$ of potassium sorbet was added in each sample. Equilibrium was carried out at each water activity and temperature maintained. The weights of the samples were recorded after every $72 \mathrm{~h}$ interval till the equilibrium reached. The equilibrium was judged when the difference between the three consecutive weights did not exceed $1 \mathrm{mg}$. Chhana Murki samples took 3 to 4 weeks to equilibrate.

\section{Fitting sorption models to EMC data}

The different sorption models reported in the literature (Chirife and Iglesias, 1978) for various foods. Considering general applicability to predict sorption parameters, three models viz., $\mathrm{BET}, \mathrm{GAB}$ and Caurie were chosen to fit the experimental sorption data of Chhana murki.

\section{BET:}

$\frac{a_{\mathrm{W}}}{\left(1-a_{\mathrm{w}}\right) w}=\frac{1}{W_{\mathrm{n}} \mathrm{c}}+\frac{\mathrm{c}-1}{W_{\mathrm{n}} \mathrm{c}} \times a_{\mathrm{w}}$ .............Eq (1)

GAB :

$\frac{W}{W_{\mathrm{n}}}=\frac{G \mathrm{k} a_{\mathrm{W}}}{\left(1-\mathrm{k} a_{\mathrm{w}}\right)\left(1-\mathrm{k} a_{\mathrm{w}}+G \mathrm{k} a_{\mathrm{w}}\right)}$ ....Eq (2)

Caurie equation (Caurie, 1981) given below was used to determine the properties of sorbed water.

$\ln \frac{1}{w}=-\ln \frac{1}{c w_{n}}+\frac{2 C}{w_{n}} \ln \frac{\left(1-a_{w}\right)}{a_{w}} \quad \ldots \ldots \ldots \ldots . . . . \mathbf{E q}(3)$

Where $a_{w}$ is water activity, $W$ is equilibrium moisture content, $W_{0}$ is monolayer moisture content at percent dry basis, ' $\mathrm{C}$ ' is a constant in respective equation, ' $G$ ' is the Guggenheim constant and ' $\mathrm{k}$ ' is a correction factor for the bulk liquid.

Caurie's plot of $\left(1-a_{w} / a_{w}\right)$ vs. $\ln 1 / W$ was used to obtain slope ' $S$ '. The numbers of the adsorbed monolayer $(N)$ were obtained using the formula:

$S=\frac{2}{N}$

Percent bound or non-freezable water is the product of monolayer value in the Caurie equation and the number of adsorbed monolayer. The surface area of adsorption was determined using following formula:

$A=\frac{54.54}{S}$

To analyze the precision of fit of the sorption data to models tested the coefficient of regression $\left(\mathrm{R}^{2}\right)$, percent root mean square 
Fig. 1 Moisture sorption Isotherms of Chhana Murki at different temperatures

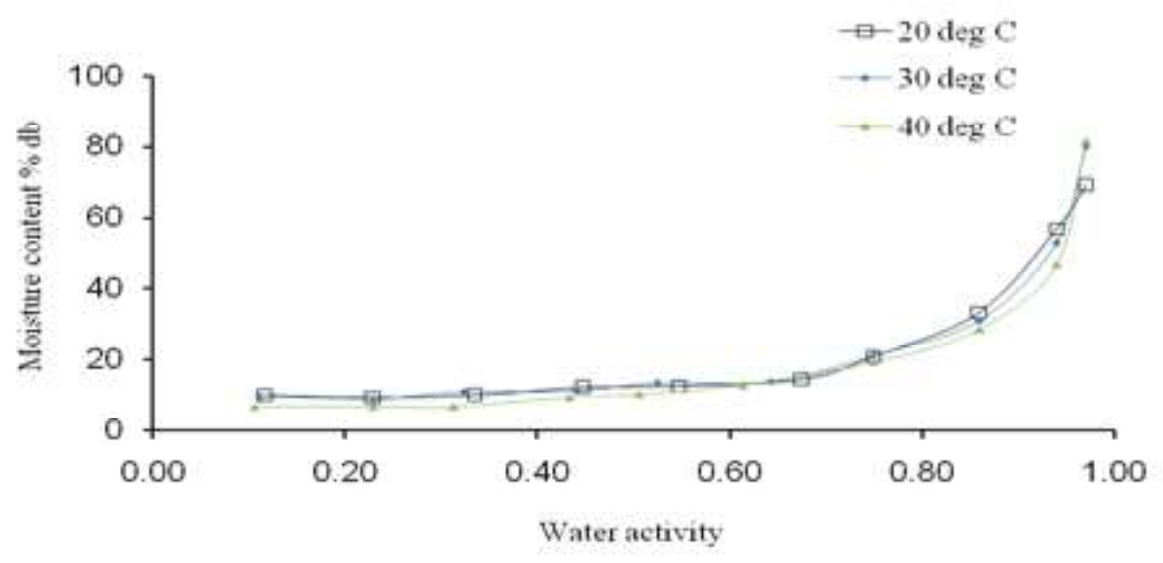

(\%RMS) error and percent deviation modulus (\%P) were estimated from the statistical formulae below:

$\mathrm{R}^{2}=\sum_{i=1}^{n} \frac{\left(x_{i}-x_{i}\right)^{2}}{\left(x_{i}-x^{-}\right)^{2}}$

$\%$ RMS $=\sqrt{\frac{1}{n}}\left[\sum_{1=1}^{\mathrm{n}}\left(\frac{x_{\mathrm{i}}-x_{\mathrm{i}}^{\mathrm{n}}}{x_{i}}\right)^{2}\right] \times 100$

$\% \mathrm{P}=\frac{1}{\mathrm{n}} \sum_{\mathrm{i}=1}^{\mathrm{n}} \frac{\left(x_{\mathrm{i}}-x_{\mathrm{i}}^{n}\right)}{x_{\mathrm{i}}} \times 100$

Where $n$ is the number of observations; $x_{i}$ is the experimental value; $x_{i}^{\wedge}$ is the value obtained by the fitting model for the $i^{\text {th }}$ observation and $x$ is an absolute mean.

\section{Net Isosteric heat of sorption}

The Clausius-Clapeyron equation (Rizvi,1995) relates to the water activities and temperatures at fixed moisture content.

$$
q_{n}^{s t}=\mathrm{R}\left[\frac{T_{1} T_{2}}{T_{n}-T_{1}}\right]\left[\ln \frac{a_{w 2}}{a_{w 1}}\right]
$$

Where, ' $q_{n}^{\text {st' }}$ is the net isosteric heat of sorption ( $\left.\mathrm{kJ} / \mathrm{mol}\right), T_{1} T_{2}$ are the absolute temperatures and ' $R$ ' is the universal gas constant $\left(8.314 \mathrm{~J} \mathrm{deg}^{-1} \mathrm{~mol}^{-1} \mathrm{~K}^{-1}\right)$. The curve of net Isosteric heat of sorption plotted against moisture content at the mean temperature represents energies for water molecules binding at a particular hydration level.

\section{Result and Discussion}

\section{Moisture sorption isotherm}

The sorption isotherms of Chhana murki were measured at the temperatures of $20^{\circ} \mathrm{C}, 30^{\circ} \mathrm{C}$ and $40^{\circ} \mathrm{C}$. The sorption isotherms from the plot of equilibrium moisture content (EMC) versus the various water activities $\left(a_{w}\right)$ at the different temperatures are presented in Figure 1. The Chhana murki isotherms obtained exhibited a sigmoid shape and corresponded to type - II BET isotherm classification according to Iglesias and Chirife (1982). This type of isotherm is typical for high carbohydrate foods as reported by Bolin (1980) and Bandyopadhyay et al. (1987). Chhana murki is high in carbohydrates as it contains $53.04 \%$ total sugars by weight. Two bends were observed in the isotherms and these could be said to be as a result of changes in the magnitude of the separate physical-chemical effects.

This could be observed from Figure 1 that the slope of the isotherms was moderate at $\quad a_{w}<0.55$ where relatively low moisture was absorbed for an increase in $a_{w}$. Above this level, there was a steep rise in the slope of isotherms for a small rise in $a_{w}$. In the low water activity region $(0.11-0.55)$, there was a small increase in EMC for a considerable increase in $a_{w}$. However, in the high $a_{w}$ region, particularly in the range of $0.68-0.97 a_{w}$, the EMC increased significantly for a small increase in $a_{w}$. The initial moisture content of Chhana murki was 39\% (dry basis) and this corresponds to water activities of $0.90,0.90$, and 0.91 at $20^{\circ} \mathrm{C}$, $30^{\circ} \mathrm{C}$ and $40^{\circ} \mathrm{C}$, respectively. This implies that the product would lose moisture when stored at relative humidity lower than $90 \%$.

Two bends and three regions could be identified for Chhana murki from figure 1, viz., region $1\left(a_{w} 0.00\right.$ to 0.33$)$, region II ( $a_{w}$ 0.33 to 0.68$)$, and region III $\left(a_{w} 0.68\right.$ to 0.97$)$. A similar observation has also been reported by Rao et. al. (2006) for Chhana podo. Moisture uptake was slow in region I, followed by a linear and steady rise in region II and subsequent rapid rise in region III. This may be due to the solubilization of sugars at high water activity range (above $0.65 \mathrm{a}_{\mathrm{w}}$ ). Region I considered as monolayer moisture region, region II indicates multilayer moisture-holding which is under transition to natural properties of free water. Some of this water is available for chemical reactions. Water in region III is in the free state held into voids, crevices, and capillaries (Kinsella and Fox, 1987). 


\section{Effect of temperature on sorption isotherm}

The effect of temperature on EMC was clearly shown in Figure 1. As the temperature increased, the EMC decreased, this implies that at any $a_{w,}$ Chhana murki becomes less hygroscopic with an increase in temperature. Since water sorption generally decreases with increasing temperature, in Chhana murki, equilibrium moisture content was lower at higher temperatures. An increase in temperature at constant moisture content causes consistent shifting of isotherm curves on the lower side which would lead to an increase in $a_{w}$, making the product more susceptible to the microbial spoilage (Labuza et. al., 1985; Bolin, 1980; Alakali and Santimehin, 2009). The negative temperature effect on the EMC has often been reported in foods with high protein content (Okos et al. 1992; Delgado and Sun, 2002a, b; Jayendra Kumar et al. 2005). The change in water activity due to temperature has been ascribed to changes in water binding, dissociation of water, and or increase of solute solubility in water as reported by Rahman (1995). It is also reported that a higher temperature results in a greater activation of the water molecules, which then breaks away from the water binding sites thereby lowering the EMC (McMinn and Magee, 2003; Sharma et al. 2009). The clear cut inversion was noticed above $0.61 a_{w}$ as all the three curves overlapped on each other for a shorter length of $\mathrm{a}_{\mathrm{w}}$ and latter followed the separate trends as earlier The curves at $20^{\circ} \mathrm{C}, 30^{\circ} \mathrm{C}$ overlapped intermittently on each other. This behavior is typical for sugar-rich food systems as a soluble component such as sugar sorb more water at higher water activity thereby overcoming the negative temperature effect due to an increase in solubility of sugar in water (Sharma et al. 2009). The effect of temperature on EMC of Chhana murki implies that at the same moisture content, the higher storage temperature will cause an increase in water activity values of the stored product above the critical level which may lead to deterioration.

\section{Evaluation of Sorption Models}

Three models viz, BET, GAB and Caurie (Eqs.1-3) were used to fit experimental data for sorption in Chhana murki and the values of the model parameters calculated are presented in Table 1 to 3 .
The statistical values of precision of fitness of sorption data are also given. It could be observed from the tables that $\mathrm{R}^{2}, \% \mathrm{RMS}$, and $\% \mathrm{P}$ values for BET, GAB \& Caurie models were validated their reliability in predicting moisture sorption behavior of Chhana murki.

Since BET model being limited to the prediction up to $0.55 \mathrm{a}_{\mathrm{w}_{\mathrm{w}}}$ GAB model could be considered as better model to predict the experimental moisture sorption phenomenon and to characterize the moisture sorption behavior in Chhana murk. GAB model is suitably fitted over an entire range of water activity and validated by $\mathrm{R}^{2}, \% \mathrm{P}$ and $\% \mathrm{RMS}$ error values presented in Table 2 .

Figure 2 shows the predicted GAB plot of Chhana murki obtained at different temperatures. This agrees with the observations of other authors who suggested that the GAB model is a useful model to predict sorption data in milk proteins and powders (Kinsella and Fox, 1987; Joupilla and Roos,1994). Rao et al. (2006) also reported the reliability of GAB model for predicting sorption data of Chhana podo. Figure 2 shows the GAB plot of Chhana murki obtained at different temperatures. The Caurie model showed relatively good predictability to define moisture sorption phenomenon in Chhana murki.

\section{Properties of sorbed water}

The values of monolayer moisture contents were obtained using GAB equation presented in Table 1. The monolayer moisture content indicates the amount of water that is strongly adsorbed to specified sites and considered the values at which food is most stable as chemical reactions are expected to be slow in this region.

Generally monolayer moisture content $\left(W_{0}\right)$ decreases with an increase in temperature (Iglesias and Chirife, 1976a,b). In Chhana murki the BET monolayer value (Table 1) was $5.77 \mathrm{~g} \mathrm{H}_{2} \mathrm{O} / 100 \mathrm{~g}$ of solids at a temperature $20^{\circ} \mathrm{C}$ and decrease to $4.83 \mathrm{~g} \mathrm{H}_{2} \mathrm{O} / 100 \mathrm{~g}$ of solids at $40^{\circ} \mathrm{C}$. The GAB monolayer value (Table 2) was 5.90 $\mathrm{g} \mathrm{H}_{2} \mathrm{O} / 100 \mathrm{~g}$ of solids at a temperature $20^{\circ} \mathrm{C}$ and decrease to 5.14 $\mathrm{g} \mathrm{H}_{2} \mathrm{O} / 100 \mathrm{~g}$ of solids at $40^{\circ} \mathrm{C}$.

Table 1 Estimated parameters of BET isotherm equation fitted to sorption data of Chhana Murki at different temperatures

\begin{tabular}{lllllc}
\hline Temp ${ }^{\circ} \mathrm{C}$ & $W_{\text {og water/ }}$ & $\mathrm{C}$ & $\mathrm{R}^{2}$ & $\% \mathrm{P}$ & $\% \mathrm{RMS}$ \\
& $100 \mathrm{~g}$ solids & & & 8.59 \\
30 & 5.77 & -16.70 & 0.9853 & 6.56 & 11.24 \\
40 & 5.62 & -9.16 & 0.988 & 6.79 & 6.26 \\
\hline
\end{tabular}

Table 2 Estimated parameters of GAB equation fitted to sorption data of Chhana Murki at different temperatures

\begin{tabular}{lllllll}
\hline Temp ${ }^{\circ} \mathrm{C}$ & $\begin{array}{l}W_{\text {og water } /} \\
\text { 100g solids }\end{array}$ & $\mathrm{k}$ & $\mathrm{C}$ & $\mathrm{R}^{2}$ & $\mathrm{P}$ & \% RMS \\
\hline 20 & 5.90 & 0.945 & -18.588 & 0.9572 & 5.94 & 6.30 \\
30 & 5.77 & 0.948 & -12.844 & 0.952 & 6.17 & 6.04 \\
40 & 5.14 & 0.959 & - & 0.9725 & 6.51 & 6.46 \\
\hline
\end{tabular}


Fig 2. GAB plot of sorption isotherms of Chhana Murki at different temperatures

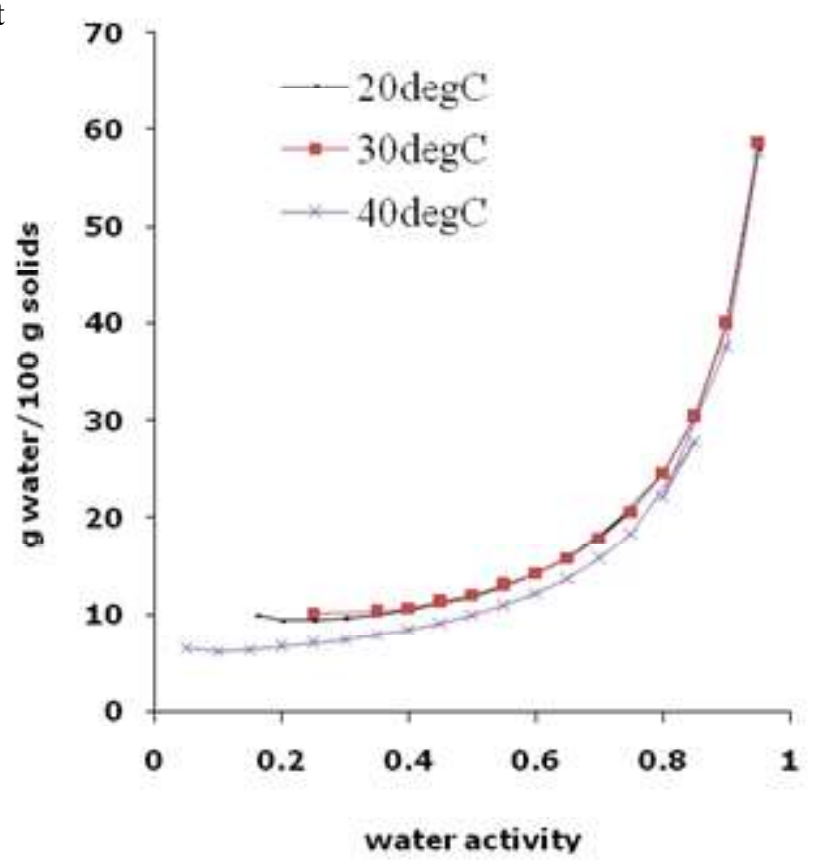

Fig 3. Net isosteric heat of sorption of Chhana Murki at different moisture content

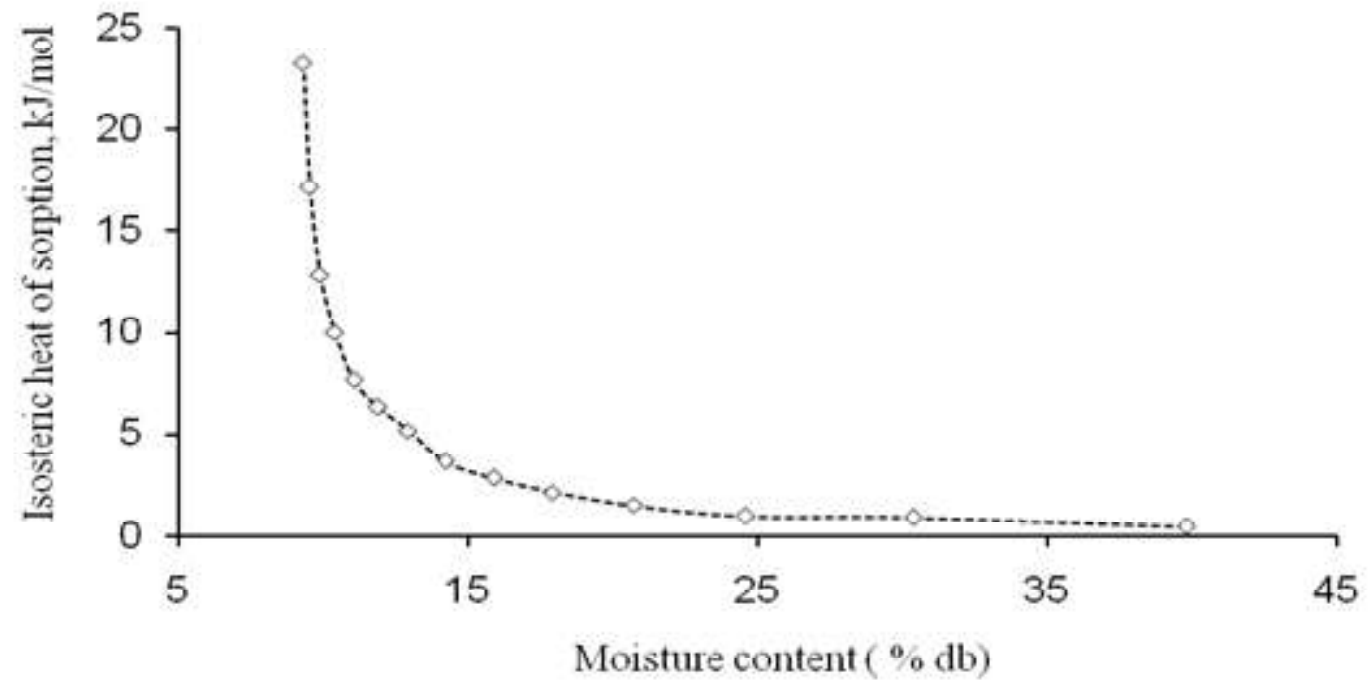

Table 3 Properties of sorbed water in Chhana Murki at different temperatures

\begin{tabular}{|c|c|c|c|c|c|c|c|}
\hline $\begin{array}{l}\text { Temp. } \\
{ }^{\circ} \mathrm{C}\end{array}$ & $\begin{array}{l}W_{\text {og water/ }} \\
100 \mathrm{~g} \text { solids }\end{array}$ & $\begin{array}{l}\text { No. of } \\
\text { Adsorbed } \\
\text { monolayers }(N)\end{array}$ & $\begin{array}{l}\text { Bound or } \\
\text { nonfreezable } \\
\text { water }(\%)\end{array}$ & $\begin{array}{l}\text { Surface } \\
\text { areaof sorption } \\
\left(\mathrm{m}^{2} / \mathrm{g}\right)\end{array}$ & $\mathrm{R}^{2}$ & $\% \mathrm{P}$ & $\% \mathrm{RMS}$ \\
\hline$\overline{20}$ & 5.62 & 3.99 & 22.42 & 108.75 & 0.97 & 10.28 & 11.99 \\
\hline 30 & 5.59 & 3.72 & 20.78 & 101.43 & 0.99 & 10.02 & 11.04 \\
\hline 40 & 5.80 & 3.53 & 20.48 & 96.26 & 0.99 & 15.62 & 18.69 \\
\hline
\end{tabular}

Hossain et al. (2002) and Rao et al. (2006) used Caurie model to characterize the sorption behavior of dudh churpi and chhana podo and suggested that Caurie model could be rated as better fit since parameters like number of adsorbed mono-layers, surface area of adsorption and percent bound water could be elucidated from the equation. Properties of sorbed water as calculated from Caurie equation for Chhana murki are presented in Table 3.

It is observed from Table 3 that the number of adsorbed monolayers decreased from 3.99 to 3.53 when temperature increases from $20^{\circ} \mathrm{C}$ to $40^{\circ} \mathrm{C}$. The bound or non-freezable water in Chhana murki decreased from $22.42 \%$ to $20.48 \%$. The surface 
area of sorption also decreased from $108.75 \mathrm{~m}^{2} / \mathrm{g}$ to $96.26 \mathrm{~m}^{2} / \mathrm{g}$ when temperature increases from $20^{\circ} \mathrm{C}$ to $40^{\circ} \mathrm{C}$ as shown in Table 3. Similar trends were also observed by Sharma et al. (2009) in ready to use basundi mix and Jayendra Kumar et al. (2005) in kheer. It was reported by Saravacos and Stinchfiled (1965) that adsorption of water can be attributed to the basic components of food such as polymeric materials viz., proteins, and soluble components e.g. sugars at high moisture content. Since all these components are present in Chhana murki, the temperature does not necessarily have a similar effect on their interaction with water and it could be said to have a varying impact of temperature on different constituents.

\section{Net isosteric heat of sorption}

The net isosteric heat of sorption represents energies for water molecules binding at a particular hydration level. This was obtained by applying the Clausius-Clapeyron equation (9) by considering $10^{\circ} \mathrm{C}$ and $40^{\circ} \mathrm{C}$ as $T_{1}$ and $T_{2}$. The curve shows the plot of Isosteric heat of sorption against moisture content of Chhana murki, plotted at the mean temperature as $25^{\circ} \mathrm{C}$. It is observed from Figure 3 that the net isosteric heat of sorption decreased with a corresponding increase in moisture content, initially rapidly (up to $15.89 \mathrm{~g}$ of water/ $100 \mathrm{~g}$ of solids) and then approaching a constant value. Similar trends were observed in studies involving many other Indian dairy products (Sharma et al. 2009; Jayendra Kumar et al. 2005; Sawhney et al. 1991).

The decrease in the net isosteric heat of sorption in Chhana murki with an increase in the amount of water sorbed is due to the availability of active sites which leads to higher energy of interaction between the sorbate and the sorption sites. As these active sites reduced, sorption occurred on less active sites giving a lower heat of sorption (Iglesias and Chirife, 1976b,c; Delgado and Sun,2002b; Jayendra Kumar et al. and 2005; Rao et al. 2006, Zungur et al. 2017). The high heat of desorption at lower moisture content could be attributed to the chemisorptions on the polar sites and also due to strained hydrogen bonds in the food solids on dehydration (Wang and Brennam,1991).

\section{Conclusions}

Moisture sorption isotherms of Chhana murki determined were sigmoid in shape and classified as type II of BET classification. The slope of the isotherms was moderate at $\quad a_{w}<0.55$ and latter there was a steep rise in the slope of isotherms for a small rise in $a_{w}$. The clear cut inversion was noticed in sorption curves above $0.61 \mathrm{a}_{\mathrm{w}}$ as all the three curves overlapped on each other for a shorter length of $\mathrm{a}_{\mathrm{w}}$, which is typical for sugar rich foods. Among the three models tested GAB model was found adequately good to predict the experimental moisture sorption data and to characterize the sorption behavior in Chhana murki. There was no significant difference observed in the monolayer values obtained from BET, GAB and Caurie models. The properties of sorbed water calculated using the data obtained from. Caurie equation. The net isosteric heat of sorption estimated using GAB parameters decreased with a corresponding increase in moisture content, the energy requirement for drying process would decrease considerably below $15.89 \%$ (d.b.) moisture content in Chhana murki.

\section{Acknowledgement}

The author acknowledges the financial support from University Grants Commission (UGC), New Delhi, INDIA for the major research project and he is grateful to the Principal, Vivekanand College, Aurangabad (Maharashtra) for providing necessary facilities to carry out this research work.

\section{References}

Alakali JS, Satimehin AA (2009) Moisture Adsorption Characteristics of Ginger (Zingiber officinale) Powders. Agricultural Engineering International: the CIGR E-journal. Manuscript 1286

Aneja RP, Mathur BN, Chandan RC, Banarjee AK (2002) Technology of Indian Milk Products. In P.R. Gupta (Ed.), New Delhi, India

AOAC (2005) Official Methods of Analysis of AOAC International. (18 ${ }^{\text {th }}$ Edn), AOAC International suite 500, 481 North Frederic Avenue Gaithersburg, Maryland, USA

Bandyopadhyay P, Das H, Sharma GP (1987) Moisture adsorption characteristics of casein, lactose, skim milk and chhana powder. J Food Sci Technol 24:6-11

Biradar US, Dev DK, Ingale UM (1985) Shelf life extension of pedha by Packaging. J Food Sci 50: 51-55

Bolin HR (1980) Retention of the water activity in prumes and raisin. J Food Sci 45: 1190- 1192

Boquet R, Chirife J, Iglesias HA (1978) Equations for fitting water sorption isotherms of foods. III. Evaluation of various three parameters models. J Food Technol 14: 527-534.

Caurie M (1981) Derivation of full range moisture sorption isotherms. In: Rockland LB,

Stewert GF (ed) Water activity: Influence on food quality. Academic Press New York, pp 63-87

Chirife J, Iglesias HA (1978) Equations for fitting water sorption isotherms of foods: Part I- a review. J Food Sci and Tech 13: 159-174

Chung D, Pfost H (1967) Adsorption and desorption of water vapor by cereal grains and their products. Part I: Heat and free energy changes of adsorption and desorption. Transaction of the ASAE 10: 549555

Delgado AE, Sun DW (2002a) Desorption isotherms and glass transition temperature for chicken meat. J Food Eng 51: 1-8

Delgado AE, Sun DW (2002b) Desorption isotherms of cooked and cured beef and pork. J Food Eng 51: 163-170

Deshmukh G, Bhadania AG, Birwal P, Datir R, Patel S (2018) Moisture sorption characteristics of Kalakand- a traditional Indian dairy product. Indian J Dairy Sci 71: 28-34

Gautam AK, Tanweer A, Bhardwaj A, Jha A (2018) Thermodynamic analysis of experimental sorption isotherms of dietetic chhana kheer. Madridge J Food Technol 3: 126-131

Ghayal G, Jha A, Sahu JK, Kumar A, Gautam A (2013) Moisture sorption isotherms of dietetic Rabri at different storage temperatures. Int $\mathrm{J}$ Dairy Technol 66: 587-594

Greenspan L (1977) Humidity fixed points of binary saturated aqueous solutions. J Res National Bureau Stand -A Phys Chem 81 A: 89-96

ISI (1981) Handbook of Food Analysis Part XI Dairy Products. Bureau of Indian Standards, New Delhi 
Hossain SA, Pal PK, Sarkar PK, Patil GR (2002) Moisture sorption characteristics of $d u d h$ churpi, a traditional milk products in India. Nahrung 46: 136-140

Iglesias HA, Chirife J (1976a) Prediction of the effect of temperature on water sorption isotherm of food material. J Food Technol 11: 109116

Iglesias HA, Chirife J (1976b) Equilibrium moisture content of air dried beef, dependence on drying temperature. J Food Technol 11: 565573

Iglesias HA, Chirife J (1976c) Isosteric heat of water sorption on dehydrated foods. Part I. analysis of differential heat curves. LebensmittelWissenchaft und Technologie 9: 116-122

Iglesias HA, Chirife J (1982) Handbook of Food Isotherms: Water sorption parameters for food and food components. Academic Press, New York

Jayendra Kumar A, Singh RRB, Patil GR, Patel AA (2005) Effect of temperature on moisture desorption isotherm of kheer. LibensmittelWissenschaft und Technologie 38: 303-310

Joupilla K, Roos YH (1994) Water sorption and time-dependent phenomena of milk powders. J Dairy Sci 77: 1798-1808

Khojare AS (2018) Moisture sorption characteristics of Shrikhand at $20^{\circ} \mathrm{C}$ and $30^{\circ} \mathrm{C}$. Indian J Dairy Sci 71: 381-388

Khojare AS (2014) Moisture Sorption Hysteresis in Sandesh at $20^{\circ} \mathrm{C}$. Asian J Dairy Food Res 33: 179-182

Khojare AS, Hembade AS (2015) Moisture adsorption characteristics of sandesh powder. Indian J Dairy Sci 69: 259-266

Kinsella JE, Fox PF (1987) Water sorption by proteins: milk and whey proteins. Bulletin of International Dairy Federation No. 209 pp 1240

Kumar A, Jha A, Jain P, Sahu JK, Arora S (2012) Moisture sorption characteristics of lal peda at different storage temperatures. Food Res Int 49: 373-378

Labuza TP, Kaanene A, Chen JY (1985) Effect of temperature on the moisture sorption isotherms and water activity shift of two dehydrated food. J Food Sci 50: 282-391

McMinn WAM, Magee TRA (2003) Thermodynamic properties of moisture sorption of potato. J Food Eng 60: 157-165

Okos MR, Narsimhan G, Singh RK, Weitnauer AC (1992) Food dehydration. In: Heldman DR, Lund DB (ed) Handbook of Food Engineering, Marcel Dekker, New York pp 437-562

Puri R, Khamrui K (2016) Effect of temperature on sorption isotherms and thermodynamics of intermediate moisture category Indian milk product cham-cham. J Food Process Preserv 40: 999-1009

Quadri SA, Khojare AS, Ingle MP (2016) Sorption Characteristics of bottle gourd burfi. Acta Scientifica Int J Food Nutr 1: $42-53$
Rahman S (1995) Water activity and sorption properties of foods. In: Food properties Handbook, CRC Press, Bocaraton, FL. pp 1-86

Ramakrishna C, Ponnachanna CS, Reddy S (2005) Moisture sorption characteristics of milk burfi, traditional Indian sweet, using sugar substitutes. Eur Food Res Technol 220: 136-141

Rao KJ, Dhas PHA, Emerald FME, Ghosh, BC, Balasubramanyam BV, Kulkarni S (2006) Moisture sorption characteristics of Chhana podo at $5^{\circ} \mathrm{C}$ and $35^{\circ} \mathrm{C}$. J Food Eng 76:453-459

Rizvi SSH (1995) Thermodynamic properties of food in dehydration. In: Rao MA and Rizvi SSH (ed) Engineering properties of foods, 2nd edn, Academic Press, New York, pp. 223-309

Sablani SS, Rahman M, Labuza, TP (2001) Measurement of Water activity using Isopiestic Method. In: Current Protocols in Food Analytical Chemistry, John Wiley \& Sons, Inc. pp A2.3.1-A 2.3.10

Sahu JK, Das H (2010) Moisture sorption isotherms, properties of sorbed water and heat of sorption of sandesh-an Indian milk product. J Food Process Preserv 34: 152-166

Saravacos GD, Stinchfield RM (1965) Effect of temperature and pressure on sorption and water vapour by freeze dried food materials. J Food Sci 30: 779-786

Sawhney IK, Cherian M (1988) Moisture sorption characteristics of heat desiccated whole milk product (khoa) 21:239-241

Sawhney IK, Patil GR, Kumar B (1991) Effect of temperature on the moisture sorption isotherms of a heat-treated whole milk product, khoa. J Dairy Res 58: 329-335

Sharma P, Singh RRB, Singh AK, Patel AA, Patil GR (2009) Sorption isotherms and thermodynamics of water sorption of ready-to-use Basundi mix. Libensmittel- Wissenschaft und Technologie 42: 441-445

Van den Berg C, Bruin S (1981) Water activity and its estimation in food systems: Theoretical aspects. In: Rockland LB, Stewert GF (ed) Water activity: Influences on food quality. Academic Press, New York, pp 1-62

Varghese SK, Nair SV, Mishra HN (2008) Moisture sorption characteristics of curd (Indian yogurt) powder. Int J Dairy Technol 62: 85-92

Wang N, Brennan JG (1991) Moisture sorption characteristics of potatoes at four temperatures. J Food Eng 14: 269-287

Zungur BA, Koç M, Kaymak E (2017) Moisture sorption isotherm of microencapsulated

extra virgin olive oil by spray drying. Food Measure 11:1295-1305 